\title{
筋疲労時の疾走能力と体力的要因との関係
}

\author{
尾縣 貢* 福島洋樹** 大山圭悟*** \\ 安井年 ${ }^{*} \quad$ 関岡康雄*
}

\section{RELATIONSHIP BETWEEN SPRINT ABILITY UNDER THE CONDITION OF MUSCULAR FATIGUE, AND PHYSICAL FITNESS FACTORS}

Mitsugi Ogata, Hiroki Fukushima, Keigo Ohyama, Toshifumi Yasui and Yasuo Sekioka

\begin{abstract}
The influence of aerobic and anaerobic components of muscular endurance on the lower limbs, on sprint ability while under conditions of muscular fatigue, was investigated. Fifteen track and field athletes $(400 \mathrm{~m}$ sprinters, decathletes and middle distance runners) participated in the study in which running and sprinting movements at respective points $(360 \mathrm{~m}$ and $50 \mathrm{~m})$ along two distance conditions ( $400 \mathrm{~m}$ and $80 \mathrm{~m}$, respectively), were filmed by high-speed video camera. Running speeds at each point were computed from the film analysis. The running speed at $360 \mathrm{~m}$ point was defined as the speed under fatigue, while the running speed at the $50 \mathrm{~m}$ point was defined as the maximal speed. Further, the rate between speed under fatigue and maximal speed was defined as \% Max. Speed. Maximal $\mathrm{O}_{2}$ intake, $\mathrm{O}_{2}$ debt and isokinetic muscular endurance were measured.

The results were summarized as follows:

1) Oxygen debt showed significant correlation with the average speed during $400 \mathrm{~m}$ running $(r=0.546 ; p<0.05)$, but not with the speed under fatigue $(r=0.388 ; p>0.05)$.

2) Speed under fatigue was positively correlated with muscular endurance of hip flexion and extension ( $r=0.683 ; p<0.01, r=0.572 ; p<0.05)$.

3) Percent Max. Speed was negatively correlated with the maximal speed $(r=-0.643: p<$ $0.01)$ and positively correlated with the muscular endurance of hip flexion and extension, and knee flexion $(r=0.640 ; p<0.05, r=0.517 ; p<0.05, r=0.646 ; p<0.01)$.

These results suggest that; raising \% Max. Speed to improve the muscular endurance of lower limbs and, to improve aerobic ability by developing the number of capillaries in the muscle, is important.

(Jpn. J. Phys. Fitness Sports Med. 1998, $47: 535 \sim 542$ )

key words : $400 \mathrm{~m}$ running, Running speed under muscular fatigue, Muscular endurance, Oxygen intake
\end{abstract}

\section{I. 目的}

$400 \mathrm{~m}$ 走の走り方に関しては, 前半 $200 \mathrm{~m}$ では リラックスを心掛けてリズミカルに，最後の直走 路(ラスト $80 \mathrm{~m}$ )ではフォームをまとめて全力を 出し切るという指導が行われる ${ }^{1,2)}$. Karlsson et $\mathrm{al}^{3)}$, Tesch ${ }^{4)}$ は, $400 \mathrm{~m}$ 走のラストでは乳酸の蓄 積と筋のアシドーシスが解糖系の機能を阻害し速
度派隇が起こるとし, Hirvonen et al. ${ }^{5)}$ は, 筋の $\mathrm{CP}$ が枯渇し, 乳酸の蓄積が最大になることが速 度莪隇の原因であると指摘している。また，伊藤 たち6)は, $400 \mathrm{~m}$ 走レースにおける $350 \mathrm{~m}$ 地点で は $150 \mathrm{~m}$ 地点と比較して, 筋疲労により走動作 はかなり変容すると報告している，以上の指摘か らすると, $400 \mathrm{~m}$ 走のラストは, 筋疲労との闘い であり，筋が疲労困借した状態での全力疾走とい
*筑波大学体育科学系

テ305-8574 茨城県つくば市天王台1-1-1

**富山商船高等専門学校

干933-0235 富山県新湊市海老江練合 1-2

*** 筑波大学大学院体育科学研究科 テ305-8574 茨城県つくば市天王台1-1-1
Institute of Health and Sciences,University of Tsukuba, Tennodai

1-1-1. Tuskuba, Ibaraki, 305-8574

Toyama National College of Maritime Technology, Ebineneriai, Shinminato, Toyama, 933-0235

Doctoral Program in Health and Sport sciences, University of Tsukuba, Tennodai 1-1-1, Tuskuba, Ibaraki, 305-8574 
うことができる.

沼沢・杉浦 ${ }^{7)}$ は，世界陸上東京大会の男子 400 $\mathrm{m}$ 決勝のレース分析を行い,ゴールタイムと 200 〜 300 m, 300 400 m の所要タイムとの間に有意 な相関関係があり, 特にラスト $100 \mathrm{~m}$ 区間がゴー ルタイムに強い影響を及はしていることを報告し ている.

これらのことから $400 \mathrm{~m}$ 走のパフォーマンス を高めるためには, レースの後半で筋疲労に耐え， いかに高い疾走速度を維持するかが重要であるこ とは明白である，実際にトレーニング現場では， いろいろな距離でのランニングやウエイトトレー ニングなどを用いて走速度持続に要求される体力 的要因を改善する努力をしている8). しかし、こ れまでに $400 \mathrm{~m}$ 走のパフォーマンスと体力的要 因との関係については報告 ${ }^{9 \sim 12)}$ があるものの, 筋疲労時における疾走能力と体力的要因との関係 を検討した報告がないため，この能力を改善する ためのトレーニングに関する的確な知見は得られ ていないのが現状である。筋疲労時における疾走 能力に影響を及ほす体力的要因を明確にすること により, $400 \mathrm{~m}$ 走をはじめ, $800 \mathrm{~m}$ 走などのトレー ニングを行ううえでの知見が得られると考える.

そこで, 本研究では $400 \mathrm{~m}$ 走中の $360 \mathrm{~m}$ 地点 の疾走速度を測定するとともに，その速度の最大 疾走速度に対する割合を明確にし, 酸素搷取能力, 酸素負債能力, 最大筋パワーおよび筋持久性など の体力的要因との関係を検討した.

\section{II. 方法}

\section{A. 被験者}

被験者には，陸上競技部に所属する男子大学生 16名を用いたが，そのうち 1 名は， $400 \mathrm{~m}$ 走の実 験時測定記録が自己記録に比較して極端に低いた め削除した。被験者 15 名の内訳は, $100 \cdot 200 \mathrm{~m}$ 走を専門とする者 2 名, $400 \mathrm{~m}$ 走を専門とする者 5 名, $800 \mathrm{~m}$ 走を専門とする者 2 名, 混成競技を 専門とし $400 \mathrm{~m}$ 走を得意とする者 6 名であった. 被験者の年齢は, $20.3 \pm 1.4$ 才(平均士標準偏差), 身長は, $1.781 \pm 0.049 \mathrm{~m}$, 体重は, $70.2 \pm 6.3 \mathrm{~kg}$, $400 \mathrm{~m}$ 走公認最高記録は, $48.90 \pm 1.18 \mathrm{~s}$ であっ
た. 1 名は, $400 \mathrm{~m}$ 走公認記録がないため実験時 の記録を用いた。

\section{B. 疾走能力の測定}

十分なウォーミングアップの後, $80 \mathrm{~m}$ 走を実 施し, 十分な回復時間を置き, $400 \mathrm{~m}$ 走を実施した。 $80 \mathrm{~m}$ 走は, 直線レーンを用い,レースを想定 して1 人ずつクラウチングスタートからピストル の合図で行った。スタートから 45〜 $55 \mathrm{~m}$ 区間の 疾走動作を $50 \mathrm{~m}$ 地点の側方からハイスピードビ デオカメラ(NAC 社製 HSV-400，200コマ/秒)に よりパンニング撮影を行った. $45 \sim 55 \mathrm{~m}$ 区間の レーン両側に $1 \mathrm{~m}$ 間隔で較正器を置いた.

$400 \mathrm{~m}$ 走は, $400 \mathrm{~m}$ トラック 6 レーンを用い, $400 \mathrm{~m}$ 走レースを想定して 1 人ずつクラウチング スタートからピストルの合図で行った。スタート から 355 365 $\mathrm{m}$ 区間の疾走動作を $360 \mathrm{~m}$ 地点側 方からハイスピードビデオカメラによりパンニン グ撮影を行った。 $355 〜 365 \mathrm{~m}$ 区間のレーン両側 に $1 \mathrm{~m}$ 間隔で較正器を置いた。

本研究では, $80 \mathrm{~m}$ 走中の $50 \mathrm{~m}$ 付近の疾走を全 力疾走, $400 \mathrm{~m}$ 走中の $360 \mathrm{~m}$ 付近の疾走を筋疲労 時疾走と定義した. ペースに関しては特別な指示 を与えなかったが，レースに近い筋疲労状態を導 くために,「ゴールでは余力が残らないようにレー スを想定して走る.」という趣旨の指示を行った。

全力疾走では $50 \mathrm{~m}$ 地点付近, 筋疲労時疾走で は $360 \mathrm{~m}$ 地点付近における左足接地から再び左 足が接地するまでの 1 サイクルをそれぞれビデオ 分析対象とした．撮影したビデオ画像は，ビデオ プレイヤーからパーソナルコンピュータ（NEC PC $9801 \mathrm{RX}) に$ 送り，スーパーインポーズ機能を用 いることにより23点の身体分析点と較正点 4 点の 座標を読み取った。この座標データを実長に換算 した後, ディジタルフィルター法により適性周波 数で平滑化した.

平滑化されたデータより疾走能力を示す以下の 項目を算出した。

(1) ストライド：1サイクル中(倍歩)の重心の 水平移動距離を算出し，それを 1 歩あたりに 換算したもの. 身長比も算出した。 
(2) ピッチ：1サイクルに要した時間の逆数を 2 倍することで, 1 歩あたりに換算したもの.

（3) 疾走速度：ストライドとピッチの積.

(4) 筋疲労時疾走速度の全力疾走速度に対する 割合：(筋疲労時疾走速度/全力疾走速度) $\times$ 100. \% Max. Speed と定義する。

\section{C. 最大酸素攝取量の測定}

最大酸素摂取量は，トレッドミルを用いた負荷 漸増法により，Exhaustion に至るまでランニン グを続ける方法により測定した．走路の傾斜は， $0 \mathrm{deg}$, 走速度は, $200 \mathrm{~m} / \mathrm{min}$ から開始し, Exhaustion まで 1 分間に $10 \mathrm{~m} / \mathrm{min}$ ずつ増加させ るようにした. Exhaustion time は, 10〜12分の 範囲にあった。走行中の呼気の採取は, 自動呼気 ガス分析器 (Mijnhardt 社, OXYCON GAMMA)に より行った。最大酸素摂取量の判断基準には, 酸 素摂取量のレベリングオフを用いた。

\section{D. 酸素負債量の測定}

本研究では, 測定を簡略化し, 被験者への負 担を小さくするという観点から，50秒程度で Exhaustion に至るトレッドミル運動後15分間の 酸素負債量を全身の無気的運動能力の指標として 採用した。なお, 尾縣たち ${ }^{10)}$ は, 無気的運動能 力の指標として，15分間で測定した酸素負債量で も有用であると指摘している．走路の傾斜は， 5.0 $\mathrm{deg}$, 走速度は, $400 \mathrm{~m}$ 走タイムを考慮して被験 者により $320 \sim 340 \mathrm{~m} / \mathrm{min}$ に設定し, Exhaustion に至るまで運動を続けさせた。被験者の Exhaustion time は, 約50 60秒の範囲であり, 運動時 間が60秒を越えた者に関しては，速度を $10 \mathrm{~m} / \mathrm{min}$ 増加させた。運動後15分間の呼吸を自動呼気ガス 分析器 (Mijnhardt 社, OXYCON GAMMA)により 分析し, その酸素摄取量から安静時酸素摄取量を 減じて, 酸素負債量を算出した。

\section{$E$ ．下肢の等速性筋持久力の測定}

等速性筋力測定器 (CYBEX NORM $\left.{ }^{\mathrm{TM}}\right)$ を用い, $3.14 \mathrm{rad} / \mathrm{s}$ の角速度で, 全力での膝関節伸展 · 屈曲, 股関節伸展・屈曲の50回連続試技を行っ
た，膝関節伸展・屈曲測定では椅子座位姿勢，股 関節伸展・屈曲では仰臥姿勢を取り，いずれの測 定でも体幹部，測定と反対脚を専用のベルトによ り固定した，測定する関節動作範囲は，膝関節, 股関節ともに完全伸展位から完全屈曲位までとし た。被験者には，測定前に測定器に慣れるように 練習時間を設けた。また, 測定前にはキャリブレー ションを行い，下肢重量による影響を取り除くた めの補正を行った.

得られたデータから，50回の試技を前半25回， 後半25回に分け，それぞれの仕事量の合計を出 し, 後半25回/前半 25 回 $\times 100$ を算出した。これを CYBEX NORM $^{\mathrm{TM}}$ では Endurance ratio という解 析項目として算出され，筋力発揮の持久性の指標 として用いられており, 本研究では筋持久性指標 と定義した。

また，上記の 50 回連続試技中 (角速度 3.14 $\mathrm{rad} / \mathrm{s})$ に記録されたピークパワーを等速性最大筋 力と定義した．なお，ランニングにおける身体の 移動速度には体重が影響を及ぼすと考えられるた め, ピークパワーは体重比とした。

\section{III. 結果}

表 1 は，全力疾走と筋疲労時疾走における走速 度，ストライド比，ピッチの平均值と標準偏差お よび両疾走間での比較を示したものである．全力 疾走速度は $9.766 \pm 0.384 \mathrm{~m} / \mathrm{s}$, 筋疲労時疾走速 度は, $7.313 \pm 0.301 \mathrm{~m} / \mathrm{s}$ であり，その差 2.453 $\mathrm{m} / \mathrm{s}$ は, $0.1 \%$ 水準で有意であった。 また，筋疲 労時疾走におけるピッチとストライド比は,それ ぞれ $3.544 \pm 0.160 \mathrm{~Hz}, 1.159 \pm 0.033$, 全力疾走 時は $4.382 \pm 0.113 \mathrm{~Hz}, 1.252 \pm 0.041$ であり,ピッ チとストライド比ともに $0.1 \%$ 水準で有意差が認 められた。

表 2 は, 全力疾走速度, 筋疲労時疾走速度, $\%$ Max. Speed および $400 \mathrm{~m}$ 平均走速度の間の相 関係数を示したものである. $400 \mathrm{~m}$ 平均走速度 は，筋疲労時疾走速度 $(\mathrm{r}=0.885, \mathrm{p}<0.001)$ と\% Max. Speed $(\mathrm{r}=0.539, \mathrm{p}<0.05)$ との間に有意な 正の相関関係が認められた。 また，\%Max. Speed は, 全力疾走速度 $(\mathrm{r}=-0.643, \mathrm{p}<0.01)$ との間 
Table 1. Comparison of stride length, stride frequency and running speed between the $50 \mathrm{~m}$ point during $80 \mathrm{~m}$ running, and the $360 \mathrm{~m}$ point during the $400 \mathrm{~m}$ running.

\begin{tabular}{lccc}
\hline \multicolumn{1}{c}{ Variables } & $50 \mathrm{~m}$ & $360 \mathrm{~m}$ & Rate $(\%)$ \\
\hline Stride length $(\mathrm{m})$ & $2.229 \pm 0.079$ & $2.065 \pm 0.083$ & $92.6^{* * *}$ \\
Stride length/Body height & $1.252 \pm 0.041$ & $1.159 \pm 0.033$ & $92.6^{* * *}$ \\
Stride frequency $(\mathrm{Hz})$ & $4.382 \pm 0.113$ & $3.544 \pm 0.160$ & $80.9^{* * *}$ \\
Running speed $(\mathrm{m} / \mathrm{s})$ & $9.766 \pm 0.384$ & $7.313 \pm 0.301$ & $74.9^{* * *}$ \\
\hline
\end{tabular}

$50 \mathrm{~m}$; at $50 \mathrm{~m}$ point from the start during $80 \mathrm{~m}$ running

$360 \mathrm{~m}$; at $360 \mathrm{~m}$ point from the start during $400 \mathrm{~m}$ running

Rate : $360 \mathrm{~m} / 50 \mathrm{~m} \times 100$

$* * * ; p<0.001$

Table 2. correlation coefficients among variables relating to the running ability.

\begin{tabular}{lcccc}
\hline \multicolumn{1}{c}{ Variables } & $(1)$ & $(2)$ & $(3)$ & (4) \\
\hline (1) Speed at $50 \mathrm{~m}$ & - & & \\
(2) Speed at $360 \mathrm{~m}$ & 0.105 & - & - & \\
(3) Rate of speed, $360 \mathrm{~m} / 50 \mathrm{~m}$ & $-0.643^{* *}$ & $0.693^{* *}$ & - & - \\
(4) Av. Speed. $400 \mathrm{~m}$ & 0.197 & $0.885^{* * *}$ & $0.539^{*}$ & - \\
\hline
\end{tabular}

$50 \mathrm{~m}$; at $50 \mathrm{~m}$ point from the start during $80 \mathrm{~m}$ running

$360 \mathrm{~m}$; at $360 \mathrm{~m}$ point from the start during $400 \mathrm{~m}$ running

Av. Speed. $400 \mathrm{~m}$; Average speed of $400 \mathrm{~m}$ running

$* * * ; p<0.001 * * p<0.01 * ; p<0.05$

に有意な負の相関関係が, 筋疲労時疾走速度 $(\mathrm{r}=$ $0.693, \mathrm{p}<0.01)$ との間には有意な正の相関関係 が認められた.

表 3 は, 全力疾走速度, 筋疲労時疾走速度, $\%$ Max. Speed と体力測定項目との関係を示して いる. $400 \mathrm{~m}$ 平均走速度は, 酸素負債量 $(r=0.546$, $\mathrm{p}<0.05)$, 股関節屈曲持久性指標 $(r=0.524$, $\mathrm{p}<0.05)$ との間に有意な正の相関関係が認めら れた. 全力疾走速度は, 股関節屈曲ピークパワー $(\mathrm{r}=0.568, \mathrm{p}<0.05)$ との間に, 筋疲労時疾走速 度は, 股関節屈曲持久性指標 $(r=0.683, p<0.01)$ および股関節伸展持久性指標 $(\mathrm{r}=0.572, \mathrm{p}<0.05)$ との間にそれぞれ有意な正の相関関係が認められ た. \%Max. Speed は, 最大酸素摄取量 $(r=0.515$, $p<0.05)$, 股関節屈曲持久性指標 $(r=0.640$, $\mathrm{p}<0.05)$, 股関節伸展筋持久性指標 $(r=0.517$, $\mathrm{p}<0.05)$, 膝関節屈曲持久性指標 $(r=0.646$, $\mathrm{p}<0.01)$ および股関節伸展ピークパワー $(\mathrm{r}=$ $-0.573, \mathrm{p}<0.05)$ との間に有意な正の相関関係 が認められた。
N.

16 名の被験者のうち 1 名は, $400 \mathrm{~m}$ 走の自己記 録に対する実験時の $400 \mathrm{~m}$ 走記録が低いため, 全力を出し切れていないと判断して被験者から削 除した. 削除した 1 名の $400 \mathrm{~m}$ 走自己記録に対 する実験時 $400 \mathrm{~m}$ 走記録の比率 (達成率, \%) は $91.8 \%$ であり, 他の 15 名の被験者は $93.5 \%$ 以上, 平均で $95.7 \%$ であった。これは, $400 \mathrm{~m}$ ランナー を対象に $400 \mathrm{~m}$ 走の全力試技を課した Hirvonen et al. ${ }^{5)}$ の実験における達成率 $93.8 \%$, Rusko et $\mathrm{al}^{12)}$ の $94.8 \%$ に比較しても高い值であった。達 成率が顕著に低い 1 名を被験者から削除したこ と, 達成率の平均が高いことから, $360 \mathrm{~m}$ 地点で はレースに近い筋疲労状態にあり，また， $360 \mathrm{~m}$ の距離を走ることによる負荷の強さもかなり統一 されていたと推測できる。

\section{A. 筋疲労時疾走能力と体力的要因との関係}

最近ではバイオメカニクス的な立場から短距離 
Table 3. Results of physical fitness measurements, and their relationship with variables relating to the running ability.

\begin{tabular}{lrcccc}
\hline & & \multicolumn{3}{c}{ Correlation coefficient } \\
\cline { 3 - 6 } \multicolumn{1}{c}{ Variables } & Mean \pm S. D. & $\begin{array}{c}\text { Speed } \\
\text { at } 50 \mathrm{~m}\end{array}$ & $\begin{array}{c}\text { Speed } \\
\text { at } 360 \mathrm{~m}\end{array}$ & $\begin{array}{c}\text { Rate } \\
360 \mathrm{~m} / 50 \mathrm{~m}\end{array}$ & $\begin{array}{c}\text { Av. speed. } \\
400 \mathrm{~m}\end{array}$ \\
\hline $\mathrm{O}_{2}$ debt $(\mathrm{ml} / \mathrm{kg})$ & $125.7 \pm 13.0$ & $0.518^{*}$ & 0.388 & -0.080 & $0.546^{*}$ \\
$\mathrm{O}_{2}$ intake $(\mathrm{ml} / \mathrm{min} / \mathrm{kg})$ & $57.8 \pm 5.9$ & -0.339 & 0.322 & $0.515^{*}$ & 0.305 \\
Muscular endurance ratio $(\%)$ & & & & & \\
Knee extension & $55.1 \pm 6.8$ & -0.304 & 0.357 & 0.507 & 0.242 \\
Knee flexion & $54.8 \pm 9.8$ & -0.371 & 0.466 & $0.646^{* *}$ & 0.477 \\
Hip extension & $71.6 \pm 11.8$ & -0.111 & $0.572^{*}$ & $0.517^{*}$ & 0.476 \\
Hip flexion & $64.5 \pm 9.5$ & -0.150 & $0.683^{* *}$ & $0.640^{* *}$ & $0.524^{*}$ \\
Peak power $(\mathrm{W}$ att/kg) & & & & & \\
Knee extension & $7.25 \pm 0.85$ & 0.002 & 0.125 & 0.086 & -0.095 \\
Knee flexion & $4.99 \pm 0.50$ & 0.342 & -0.149 & -0.376 & -0.086 \\
Hip extension & $11.14 \pm 1.63$ & 0.375 & -0.402 & $-0.573^{*}$ & -0.406 \\
Hip flexion & $6.53 \pm 0.94$ & $0.568^{*}$ & -0.144 & 0.513 & 0.004 \\
\hline
\end{tabular}

$50 \mathrm{~m}$; at $50 \mathrm{~m}$ point from the start during $80 \mathrm{~m}$ running $360 \mathrm{~m}$; at $360 \mathrm{~m}$ point from the start during $400 \mathrm{~m}$ running AV. Speed. $400 \mathrm{~m}$; Average speed of $400 \mathrm{~m}$ running ${ }^{* *} ; p<0.01 \quad * ; p<0.05$

疾走における股関節周辺筋群と股関節動作の重要 性が指摘されている．伊藤たち ${ }^{6)}$ は，キック中の 下肢動作で股関節伸展動作が最も重要で, 疾走速 度を決定づける大きな要因であると指摘してい る. 阿江たち ${ }^{13)}$ は, 股関節伸展筋群は支持期後 半での身体の加速, 回復期後半での大腿の振り戻 し, 股関節屈曲筋群は体幹の安定, 回復期前半で の大腿の振りだしという機能を持つため，股関節 周辺の筋群を強化することは短距離疾走能力を高 めることにつながると指摘している。 また，尾縣 たち ${ }^{14)}$ は, Cybex II により測定した股関節屈曲 筋力の優れていることがキック後素早く大腿を前 方に振り出すことを，また股関節伸展筋力の優れ ていることが接地局面で支持脚を速く後方にス ウィングすることを可能にし，それらが疾走能力 を高めることに貢献していることを明らかにして いる.

本研究では，股関節伸展・屈曲運動の持久性に 優れている者が筋疲労時疾走能力に優れていると いう結果が得られた. $400 \mathrm{~m}$ 走における $360 \mathrm{~m}$ 地 点は, $\mathrm{CP}$ の枯渇, 乳酸の蓄積, アシードシスな どの速度聥隇 ${ }^{3.45)}$ を導く要因と闘いながらの全
力疾走であり，このような生体に起こる様々な変 化により， $400 \mathrm{~m}$ 走後半では膝の上がりの低下， 脚スウィングスピードの低下などの動作変容が導 かれ疾走速度は聥隇するものと考えられる ${ }^{6)}$. 本 研究でも筋疲労時疾走のピッチ, ストライドがと もに有意に低いことから，筋疲労時では全力疾走 時に比較して, 疾走動作に差異が生じたものと推 察できる。これらのことから股関節伸展・屈曲運 動の持久性に優れている者は，筋疲労時にも全力 疾走時により近い動作で走ることができ，その結 果, 高い疾走速度を示したものと考えられる.

全身の無気的運動能力を示す酸素負債量は, $400 \mathrm{~m}$ 走平均走速度との間に有意な相関関係が認 められたが，筋疲労時走速度との間には有意な関 係が認められなかった。これは， $400 \mathrm{~m}$ 走全体で 見れば，必要なエネルギーの多くを無気的エネル ギー供給系に依存し, 全身の無気的運動能力が要 求されるが， $400 \mathrm{~m}$ 走後半に限れば，全身の無気 的運動能力よりも股関節屈曲・伸展筋群の筋持久 性の関与が強くなることを意味するものである. また，本研究では図 1 のように酸素負債量といず れの筋持久性とも有意な関係が認められなかった 


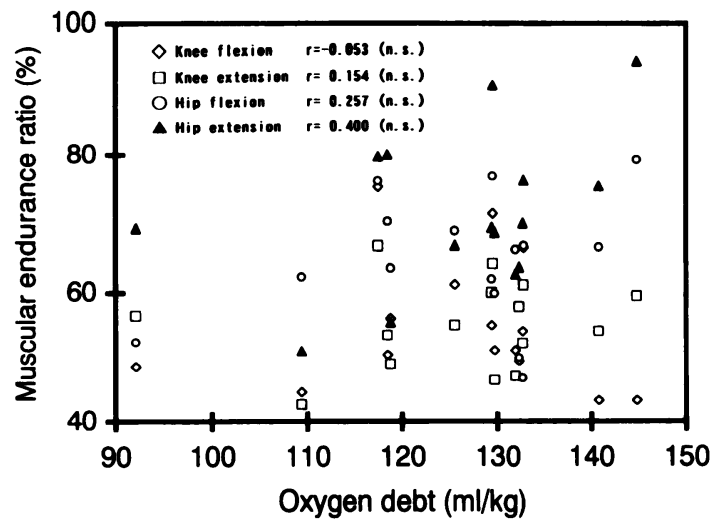

Fig. 1. Relationship between oxygen debt and muscular endurance ratio of knee and hip.

ことから継続的にトレーニングを行っている陸上 競技のランナーにおいては，局所の筋持久力は全 身の無気的運動能力の水準に影響を受けないと推 測できる。

\section{B. \%Max. Speed と体力的要因との関係}

\% Max. Speed は, 全力疾走速度と有意な負の 相関関係にあることから, 高い疾走速度を出すこ とのできる能力と, 筋疲労時において全力疾走時 により近い速度で走ることのできる能力は相反す ると考えられる。この結果が得られた原因の一つ として, 被験者の筋線維組成の違いをあげること ができる、勝田たち ${ }^{15)}$ は, 短距離選手13名, 長 距離選手17名, 十種競技選手 1 名, ハンドボール 競技選手 1 名の異質集団のなかでは，\%FT と 50 $\mathrm{m}$ 走の平均走速度とは有意な正の相関関係にあ り，12分間中の平均走速度とは負の相関関係にあ ると指摘している。これは，\%FT の高い筋は高 速度の運動で大きな筋力を発生することができる が，収縮を繰り返すと％ST の高い筋に比較し て, 疲労による筋力発揮の低隇率が大きいという 筋線維タイプの特性に裏付けられる. しかし, 一 方で麻場たち ${ }^{16)}$ は, 短距離選手のみを対象とし た等質集団では, 脚筋の \%FT は, 短距離選手と して成功する必要条件ではあるが, 疾走能力を決 定する要因には必ずしもならないことを示唆して いる. 本研究の被験者は, 短距離, 中距離, 混成 競技を専門とする勝田らの報告に近い異質集団と
考えられるため, 筋線維組成は疾走能力を規定す る一要因になり得たという推測が成り立つ.すな わち，\%FT の高い者が高い全力疾走速度と低い \% Max. Speed を示す傾向にあり，この両要因の 間に負の相関関係が認められたものと考えられ る.

\% Max. Speed は，股関節屈曲・伸展筋持久性 指標, 膝関節屈曲持久性指標および最大酸素摄取 量との間に有意な正の相関関係があった。参考ま でに％Max. Speed を従属変数, 体力測定項目を 独立変数とし重回帰分析 (ステップワイズ法)を行 い, \% Max. Speed の約 $61 \%$ は, 股関節屈曲持久 性指標, 膝関節屈曲持久性指標により説明される という知見が得られたことから％ＭMax. Speed には筋持久力的要因の関与が強いと考えられる.

これまでの研究から筋の持久性のトレーナビリ ティは高いとされている．筋の持久性の主たる規 定因子と考えられている毛細血管は持久性トレー ニングにより 2 倍に増加し ${ }^{17.18)}$. また酸化系酵 素活性も 2 倍にも高まる ${ }^{17)}$ と報告されている.

このうち毛細血管の増加は, ランナーだけでな く, 大きな力を持続することが要求されるスポー ツ選手(ボート，クロスカンツリースキーヤー)の

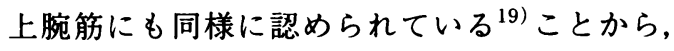
ランニングなどの持久性トレーニングだけではな く，筋力トレーニングを適切に行うことでも筋の 持久性が改善され，筋疲労時において全力疾走時 により近い速度で走ることのできる能力も向上す るものと推測できる.

股関節屈曲・伸展運動の重要性については先述 の通りであるが, 膝関節屈曲運動の持久性の重要 性についても考える必要がある，膝関節を屈曲さ せる大腿二頭筋は，接地局面ではコンセントリッ クな筋収縮により股関節を伸展させ, 身体を推進 させる機能を持っており ${ }^{20)}$ 。これまでにも短距 離疾走能力を考える上で重視されてきた。これら のことから，この筋群の持久性と股関節屈曲・伸 展運動を司る筋群の持久性は，\% Max. Speed 高めるために重要であると言える.

\% Max. Speed と有意な関係にあった最大酸素 摄取量は，一般には有気的運動能力を知る指標と 
して用いられ，短距離疾走能力を規定する要因と しては重視されていない。しかし，30秒程度で疲 労困謈に至る運動では約35\%が，60秒程度で疲労 困供に至る運動では約 $50 \%$ が有気的エネルギー供 給機構からエネルギー供給を受けていると報 告21)されていることから, $400 \mathrm{~m}$ 走においては, かなりの部分, 有気的エネルギー供給機構によっ てまかなわれていると言える。また，山本たち221 の, 最大有酸素性パワーに優れる者では自転車ぺ ダリング運動で，10秒以後の発揮パワーに優れる 傾向にあるという報告, Ivy et al. ${ }^{23)}$ の, CYBEX II を用いた膝伸展・屈曲運動では, 運動開始後 45 秒の筋パワーと最大酸素㠌取量との間に有意な相 関関係が認められるという報告から，比較的短時 間の全力運動における有気的運動能力の重要性が 確認できる. 本研究でも図 2 のように最大酸素椇 取量と膝関節屈曲持久性指標とは $\mathrm{r}=0.842(\mathrm{p}<$ $0.001)$, 膝関節伸展持久性指標とは $r=0.779$ $(\mathrm{p}<0.001)$ の有意な関係が認められている.

これらの報告から，一般に無気的運動と考えら れている短距離走にあっても有気的運動能力は重 要であると考えられる．実際に麻場たち(16) は， 最大酸素摂取量などの有気的運動能力を示す指標 との間に密接な関係がある毛細血管 (FT 線維) と 相対的持久疾走能力 $(60$ 秒間走の平均走速度/30 $70 \mathrm{~m}$ の平均走速度) との間に有意な相関関係があ ると報告している。そして毛細血管が発達すれば 筋内の酸素貯蔵量が増大し, 相対的持久疾走能力

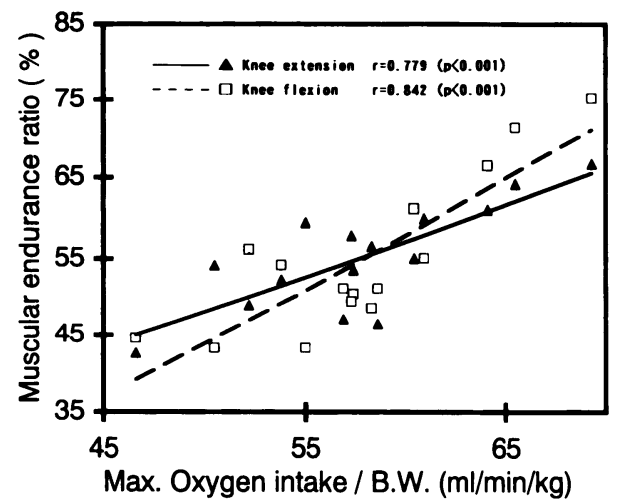

Fig. 2. Ratio between maximal oxygen intake and muscular endurance of the knee.
が高まるという関係を指摘している。これは，本 研究で得られた最大酸素摂取量が \% Max. Speed に影響を及ほすす要因であるという結果を裏付ける ものである、また，Saltin \& Gollnick ${ }^{24)}$ は，持久 性トレーニングによる最大酸素摂取量の増加は, 筋線維 1 本あたりの毛細血管数の増加に対応して いることを報告している.

これらのことから，筋疲労時において全力疾走 時により近い速度で走ることのできる能力を向上 させるためには，股関節伸展・屈曲運動と膝関節 屈曲運動の持久性を改善することと, 毛細血管を 発達させるという観点から有気的運動能力を改善 することが重要であると考えられる。

\section{V. 要 約}

本研究では $400 \mathrm{~m}$ 走後半の筋疲労状態での疾 走能力と体力的要因との関係を検討した．15名の ランナー $(400 \mathrm{~m}$ 走記録 $48.90 \pm 1.18 \mathrm{~s})$ を対象に, $80 \mathrm{~m}$ 走, $400 \mathrm{~m}$ 走のビデオ撮影および酸素摂取能 力, 酸素負債能力, 最大筋パワーおよび筋持久性 などの体力的要因の測定を行った。 ビデオ分析に より $80 \mathrm{~m}$ 走中の全力疾走速度 $(50 \mathrm{~m}$ 付近の疾走 における走速度), 筋疲労時疾走速度 $(400 \mathrm{~m}$ 走中 の $360 \mathrm{~m}$ 付近の疾走における走速度), \% Max. Speed (全力疾走速度に対する筋疲労時疾走速度の 割合)を算出した。

主な結果は次の通りである.

1）\%Max. Speed は, 全力疾走速度と有意な負 の相関関係にあったことから，高い疾走速度を 出す能力と, 筋疲労時において全力疾走時によ り近い速度で走ることのできる能力は相反する と考えられる。

2）筋疲労時疾走速度は, 股関節伸展 ・屈曲運動 の持久性指標との間に有意な正の相関関係が認 められた。

3）酸素負債量は, $400 \mathrm{~m}$ 走平均走速度との間に 有意な相関関係が認められたが, 筋疲労時疾走 速度との間には有意な関係が認められなかっ た。

4） \% Max. Speed と股関節屈曲 - 伸展筋持久性, 膝関節屈曲持久性および最大酸素摂取量との間 
に有意な正の相関関係が認められた。

(受理日 平成10年 6 月26日)

\section{女 献}

1）宮丸凱史. 短距離走. 陸上競技のコーチング I, 大修館書店, 東京, (1976), 171-298.

2）山本邦夫，永井 純. 陸上競技トラック，不昧堂, 東京, (1980).

3) Karlsson, J., Hulten, B. \& Sjodin, B. Substrate activation and product inhibition of LDH activity in human skeletal muscle. Acta Physiol. Scand., (1974),92, 21-26.

4) Tesch, P. A. Muscle fatigue in man and lactate concentration. Biomechanics IV-A, (1978), University Park Press, Baltimore, 68-72.

5) Hirvonen, J., Nummela, A., Rusko, H., Rehunen, S. \& Haerkoenen, M. Fatigue and changes of ATP. creatine phosphate, and lactate during the $400-\mathrm{m}$ sprint. Can. J. Spt.Sci., (1992), 17, 141-144.

6）伊藤 章, 市川博啓, 霅藤昌久, 伊藤道郎, 佐川 和則, 加藤謙一. アジア大会男子 $400 \mathrm{~m}$ の動作分析. アジアー流競技者の技術, ベースボールマガジン 社, 東京, (1995), 65-80.

7）沼沢秀雄, 杉浦雄策. $200 \mathrm{~m}, 400 \mathrm{~m}$ レースの時間 分析, 世界一流競技者の技術. ベースボールマガ ジン社, 東京, (1994), 50-56.

8） Mach, G. マック式短距離トレーニンク, 講談社, 東京, (1975).

9) Mero, A., Rusko, H., Peltola, E., Pullinen, T., Nummela, A. \& Hirvonen, J. Aerobic characteristics, oxygen debt and blood lactate in speed endurance athletes during training. J. Sports Med. Phys. Fitness, (1993), 33, 130-136.

10）尾䅫 貢, 福島洋榯, 大山圭悟, 安井年文, 鍋倉 賢治, 宮下 憲, 関岡康雄, 永井 純. 下肢の筋 持久性と $400 \mathrm{~m}$ 走中の疾走速度通減との関係, 体 育学研究，(1998)，42，370-379.

11) Olsen, H. L., Raabo, E., Bangsbo, J. \& Secher, N. H. Maximal oxygen deficit of sprint and middle distance runners. Eur. J. Appl. Physiol., (1994), 69, 140-146.

12) Rusko, H., Nummela, A. \& Mero, A. A new method for the evaluation of anaerobic running in athletes.
Eur. J. Appl. Physiol., (1993), 66, 97-101.

13）阿江通良, 宮下憲, 横井孝志, 大木昭一郎, 涉川 㑆二. 機械的パワーからみた疾走における下肢筋 群の機能および貢献度, 筑波大学体育科学系紀要, (1986), 9, 229-239.

14）尾県 貢, 関岡康雄, 辻井義弘. 男子スプリンター における下肢の動的筋力と疾走中の脚動作との関 係，陸上競技研究，(1990)，1，14-19.

15）勝田 茂, 高松 薏, 田中 守, 小泉順子, 久野 譜也，田㴊健一. $50 \mathrm{~m}$ 走と 12 分間走の成績による 外側広筋の箭線維組成の推定, 体育学研究, (1989), 34, 141-149.

16）麻場一徳, 勝田 茂, 高松 萫, 宮下 憲. スプ リンターの疾走能力と外側広筋の筋線維組成求よ び筋毛細血管分布との関係, 体育学研究, (1990), 35, $253-260$.

17) Holloszy, J.O \& \& Booth, F. W. Biochemical adaptation to endurance exercise in muscle. Ann. Rev. Physiol., (1976), 38, 273-291.

18) Holloszy, J.O. \& Coyle, E. F. Adaptations of skeletal muscle to endurance exercise and their metabolic consequence. J. Appl. Physiol., (1984), 56, 831-838.

19) Mizuno, M., Juel, C., Bro-Rasmussen, T., Mygind, E., Schibye, B, Rasmussen, B. \& Saltin, B. Limb skeletal muscle adaptation in athletes after training at altitude. J. Appl. Physiol., (1990), 68, 496-502.

20）伊藤 章, 斎藤昌久, 淵本隆文. スタートタッシュ 時における下肢関節のピークトルクとピークパ ワー, および筋放電パターンの変化, 体育学研究, (1997), 42, 71-83.

21) Melbo.J. \& Tabata, I. Anaerobic energy release in working muscle during $30 \mathrm{~s}$ to $3 \mathrm{~min}$ of exhausting bicycling. J. Appl. Physiol., (1993), 75, 1654-1660.

22) 山本正嘉, 中村好男, 宮下充正. 90秒間連続の最 大努力作業時に発揮されるパワーに関する研究, J. J. SPORTS SCI., (1985), 4, 308-313.

23) Ivy, J. L., Sherman, W. M., Miller, L. M., Maxwell, B. D. \& Costill, D. L. Relationship between muscle $\mathrm{QO}_{2}$ and fatigue during repeated isokinetic contraction. J. Appl. Physiol., (1982), 53, 470-474.

24) Saltin, B. \& Gollnick, P. D. Skeletal muscle adaptabilitySignificance for metabolism and performance. Hand. book of Physiology-Skeletal muscle. American Phy. siological Society, Baltimore, (1983), 555-621. 